\title{
WILLIAM A. NEWELL, CLASS OF 1836
}

\author{
BY FRANK V. SPERDUTO \\ Assistant Headmaster, Rutgers Preparatory School
}

\begin{abstract}
$A^{\mathrm{T}}$ the Rutgers College alumni dinner following graduation $A$ ceremonies in 1906, Cortlandt Parker looked back over a 1 seventy-year span and reminisced about his class, the class of 1836 :
\end{abstract}

I mention William A. Newell, perhaps the most remarkable instance of great success and complete change of college character I have ever known. Not wanting was he in cleverness, according to the estimate of those who knew him well, as I did, for we were close friends in college and even closer in after life. But he was so apparently almost contemptuous of his studies that no one, I think, ever thought that he was destined to distinction. ${ }^{1}$

Newell's undergraduate record may have been undistinguished, but having graduated, he pursued two careers concurrently, with equal vigor and considerable success. As a physician Newell enjoyed a large and profitable medical practice throughout his lifetime. At an early age, however, his keen and natural interest in public affairs drew him into the turbulent politics of the decade before the Civil War, the war itself, and the reconstruction era. Ultimately, Newell's public career carried him across the continent to the last frontiers on the Pacific shores.

William A. Newell's father, James Hugh Newell, was a largely self-educated civil engineer from Monmouth County who set out after the War of I 8 I 2 on a prospecting trip to Ohio, where William was born on September 5, I817. When William was about three years old, the family returned to New Jersey and settled in New Brunswick. William studied in local schools and with private tutors, entered Rutgers College at the age of 15 , and graduated in the class of $\mathrm{i} 836 .^{2}$

Three years later, in 1839 , Newell earned a medical degree at the University of Pennsylvania. He immediately began the practice of medicine under Dr. William Van Deursen of New Brunswick

1 The Targum, XXVI, No. 27 , June I 906, 543 .

${ }^{2}$ Cyclopedia of New Jersey Biography (New York: The American Society, Inc., 1923), I, 230. Fred B. Rogers, "William Augustus Newell (1817-190I): Physician, Governor, Congressman," The Journal of the Medical Society of New Jersey, 56, 278 . 
and in a short time he married Van Deursen's daughter Joanna. Soon an attack of pulmonary tuberculosis forced Newell to leave New Brunswick. He settled at Manahawkin on Barnegat Bay, practicing medicine with an uncle until his health was restored. In I 842 he moved to Imlaystown and finally two years later to Allentown. Those years on the New Jersey shore left a lasting impression which provided the impetus for one of Newell's most satisfying achievements in public life.

Newell's father was described as an "old line Whig" and William followed in that tradition. As early as I 840 Newell supported the Whig candidates in the colorful and significant "Tippicanoe and Tyler, Too" campaign. ${ }^{4}$ While a resident of Imlaystown, Newell had his first taste of public office, winning several terms as township collector. In 1846 at the age of twenty-nine, he was nominated by the Whig Party as candidate for a congressional seat from the second district. He won and in 1848 gained re-election.

Newell drew great satisfaction in recalling the fact that his seat in the congressional chambers was next to those of John Q. Adams and Abraham Lincoln. Newell is reputed to have administered to Adams when he suffered his fatal attack in the capitol rotunda. ${ }^{6}$

As a freshman congressman Newell moved among his colleagues to muster support for a bill which would establish life-saving stations along the New Jersey shore. Each year hundreds of lives were lost and a large amount of property destroyed in the busy and vital sea trade off the New Jersey shores. On August 3, I 848, Newell offered his bill as an amendment to the Light House Bill which had previously cleared the Senate. ${ }^{7}$ The amendment was adopted, unanimously.

Lincoln appointed him superintendent of the service, and eventually the New Jersey legislature passed resolutions recog-

${ }^{3}$ Samuel T. Wiley, Biographical and Portrait Cyclopedia of Third Congressional District of New Jersey (Philadelphia: Biographical Publishing Company, 1896), pp. I $20-121$.

${ }^{4}$ The Advance, August I 5 , I 901.

${ }^{5}$ Cyclopedia of New Jersey Biography, I, 230.

${ }^{6}$ Ibid., V, 103-104.

${ }^{7}$ Remarks of William A. Newell of New Jersey on a Proposition to Devise Means for the Preservation of Life and Property from Wrecks on the New Jersey Coast, House of Representatives, August 3, 1848 (Washington, D.C.: Printed by John T. Towers, I 848$)$. 
nizing Newell as "father of the life-saving service." In his remarks before the Monmouth County Historical Association in 1900, Newell left little doubt that such recognition was one of the most rewarding experiences in his public life. ${ }^{8}$

The clearest expression of Newell's early political views is found in his speech accepting the Whig nomination for re-election on September 20, I $848 .^{9}$ Newell believed that the Clay-Webster conservative Whig influence was absolutely essential to the nation's political life. He deplored the excesses of Jacksonianism, especially the encroachment of executive power upon the prerogatives of the legislature. Newell supported such basic Whig measures as the protective tariff and federal internal improvement projects and opposed the sub-treasury. These issues, however, yielded to the more immediate and urgent concern over the extension of slavery into the territories acquired recently at the conclusion of the Mexican War. To Newell the extension of slavery was "the question of the age." Newell claimed that the nation had sufficient territory for the next 600 years and feared that "Manifest Destiny" was merely a guise for the spread of slavery. Newell's opposition to the extension of slavery was based upon his contention that the institution was detrimental to the economic prosperity of the nation, the clear constitutional authority of the Congress to legislate in the territories, and finally, upon moral principles:

I will not be found at this the meridian of the nineteenth century, advocating or by my vote sustaining the propagation of human slavery. It is a curse to the South or any other country where it exists. It interfers by the competition of slave labor, with the interests and prosperity of the North. It prevents the immigration of free labor into territories where it exists, thus virtually excluding by far the greater portion of our population.

But there is to my mind a high moral obligation to oppose it which overrides all considerations of policy-all sectional interests-all political contingencies. ${ }^{10}$

But Newell was no radical on the slavery issue. Essentially Newell conceded the right of a state to maintain slavery; he was familiar with the evolution of slavery in the United States and the constitutional safeguards it enjoyed; these he would respect. Abolitionists and pro-

${ }^{8}$ Francis B. Lee, New Jersey as a Colony and as a State (New York: The Publishing Society of New Jersey, 1902), pp. 331-342.

9 Trenton State Gazette, September 3, $1856 . \quad{ }^{10}$ Ibid. 
slavery extremists he considered equally dangerous to the stability and preservation of the Union.

During the momentous days when Congress hammered out the Compromise of I 850 , Newell's voting record obscures somewhat his position on specific issues then before the Congress. He voted for the admission of California as a free state and against the act to organize the New Mexico Territory without the Wilmot Proviso. But no vote was recorded for the Fugitive Slave Act or the abolition of the slave trade in the District of Columbia. ${ }^{11}$

Disintegration of the Whig Party after 1852 and emergence of the Republican Party a short time later provided a complex problem for old Whigs having political aspirations. At first Newell found a haven for his conservative principles in the American Party which urged moderation in the sharpening sectional controversy. Old Whigs, Americans and Republicans struggled-frequently against one another-to organize the diverse political elements in New Jersey in a vain effort to deny Buchanan the state in I 856 .

New Jersey also held its gubernatorial election in 1856 , and the prospects for dislodging the Democratic Party which had dominated state politics since I 848 were dim. The only possibility was to drop old and new party labels and unite behind a commonly acceptable candidate. Organization of an "Opposition Party" took shape at a convention held on June 4, I 856 , at which Newell was nominated as the "Opposition" candidate.

Almost half a century later Newell remarked that in 1856 he "sawed wood and let his friends fight for him."" Although an octogenarian mellowed by time can easily fall prey to exaggerating the triumphs of his youth, this seems not to be true in Newell's case. Rather, such a course of action, or inaction, was a most positive political strategy, given the complexities and state of flux in national and state politics in 1856 .

The Democratic opposition carried out a two-fold assault upon Newell. They tried to link him with the most radical elements in the Republican and American parties. The Trenton Daily True American, a Democratic paper, labeled Newell, alternately, the

11 Journal of the House of Representatives, September 6, I850, p. 1412; September 7,1850 , p. 1424; September 12, 1850, p. 1452; September I7, 1850, p. 1486.

12 The Advance, August 15, 1901. 
"Black Republican" and "Know Nothing" candidate. At the same time the Democrats endeavored to prove that Newell's economic principles would endanger the economic privileges and prosperity enjoyed by corporations and the citizens of New Jersey. Frustrated by Newell's silence, the Democrats succumbed to minimizing Newell's role in establishing the life-saving service..$^{13}$

The Republicans backed Newell's candidacy and were most anxious to secure his endorsement for Fremont. The American Party paper, the State Gazette, reprinted Newell's I 848 speech at the Whig convention in an effort to convince Republicans that he was clearly a free-soil advocate; the Republicans were satisfied. The Gazette urged the Republicans to concentrate on the Democratic state administration, its reckless expenditures, a growing state debt, and the possibility of increased taxation. ${ }^{14}$ The Gazette repeated throughout the campaign:

He [Newell] is not the candidate of any particular party, but the candidate of the people against the candidate of the State House clique and spoils democracy. ${ }^{15}$

Although Buchanan's plurality in New Jersey exceeded 20,000 votes, Newell carried the state by 2,600 votes. ${ }^{16}$

In his inaugural address Newell pledged himself to the "strictest economy" in the operation of the government and a reduction in the state debt. ${ }^{17}$ These have always been popular objectives in New Jersey politics. He urged the legislature to restrict the issue of corporate charters and to discourage the political activities of corporations. Such statements satisfied the anti-monopolists in New Jersey who were convinced that the close ties between the powerful Camden and Amboy Railroad Company and the Democratic Party were detrimental to both the political and economic climate in the state. Anti-immigrant elements in the American Party could take heart from Newell's request for strict voter registration laws which would curtail the voting privileges of recently naturalized citizens. Many believed that corrupt politicians rushed large numbers of aliens through the naturalization process and voter registration

${ }^{13}$ Trenton Daily True American, June 9; October 11, 1 3, 30, 1856.

14 Trenton State Gazette, September 2, 3, 13, 20, 27; October 25, 27, 1856 .

15 Ibid., September 8, 1856 .

${ }_{16} \mathrm{Ibid}$., November 14, 1856 .

${ }^{17}$ New Jersey Senate Journal, January 20, i 857 , pp. 47-5x. 
prior to each major election. Newell was concerned for the "purity of the ballot box." And it was a fact that the Democratic Party stronghold in the northeastern portion of the state did have the largest immigrant population. ${ }^{18}$

A small but vocal group of temperance Whigs was encouraged by Newell's denunciation of alcoholic beverages and his call for legislative action "to diminish this fruitful source of degradation." line Whigs were reassured by Newell's expressed interest in promoting the construction of railroads, canals, and turnpikes. And finally, by condemning the Kansas-Nebraska Act, Newell confirmed and strengthened his ties with the anti-slave extension position of the Republican Party.

During his tenure Newell reiterated his views on economy in government, temperance legislation, and excessive corporate practices. Poor economic conditions after I 857 sharpened his fear of increased immigration, but he never publicly condemned foreigners in toto and there is doubt that Newell ever succumbed to xenophobia. ${ }^{20}$ New Jersey's growing industrial interests suffered also after I857, and Newell revived the traditional Whig desire for greater tariff protection. ${ }^{21}$

The New Jersey legislature was controlled by the Democrats throughout Newell's administration except briefly in I 859 when the "Opposition" forces gained a majority in the assembly. Legislative sessions were brief, little business was transacted, and few laws were passed. ${ }^{22}$ In principle Newell believed in the supremacy of the legislature, but he must have regretted the perpetual Democratic majorities which prevent the record from showing any significant legislation during the life of his administration.

${ }^{18}$ Charles Merriam Knapp, New Jersey Politics During the Period of the Civil War and Reconstruction (Geneva, N.Y.: W. F. Humphrey, 1924), p. 13. Richard P. McCormick, The History of Voting in New Jersey (New Brunswick: Rutgers University Press, 1953), pp. 131-I32.

19 New Jersey Senate Journal, January 20, I 859 , pp. 47-5 I.

${ }^{20}$ New Jersey Senate Journal Appendix, January i 2, 1859, pp. 3-29.

${ }^{21}$ Third Annual Message of William A. Newell, Governor of New Jersey, to the Senate and House of Assembly with Accompanying Documents, January I I, i 860 (Trenton: Printed at the True American Office, 1860).

${ }^{22}$ Duane Lockard, The New Jersey Governor: A Study in Political Power (Princeton: D. Van Nostrand Company, Inc., 1964), pp. 54-64. 
Newell used his appointive powers and opportunities to strengthen the "Opposition Party." Most significant was the appointment of William L. Dayton, a Republican, as attorney-general and Charles Perrin Smith, a former Whig and National American, as clerk of the Supreme Court. ${ }^{23}$

After leaving office Newell moved into the very center of the political storm which soon triggered secession and civil war. The "Opposition Party" sent a delegation to the Republican national convention in 1860 . Newell was among the New Jersey delegates who joined with Pennsylvania, Indiana and Illinois to deny William H. Seward an early nomination because of his extreme position on the slavery issue. New Jersey supported William L. Dayton, a favorite son candidate, and then united with the Lincoln forces. Lincoln's moderate position on slavery and the protective tariff plank in the Republican platform were decisive factors in securing "Opposition Party" votes. ${ }^{24}$

President Lincoln rewarded Newell with several appointments, the first, as superintendent of the life-saving service whose creation Lincoln had supported in the thirtieth Congress, and later, as chief examining physician for draftees in New Jersey. There is ample evidence to confirm Lincoln's confidence in his former congressional colleague. Newell was a primary dispenser of federal patronage in the state, for his requests to Lincoln on behalf of constituents invariably received favorable action. ${ }^{25}$ In most cases Lincoln simply wrote a brief message on the back of Newell's requests: "This is a good recommendation, and I think New Jersey is entitled to that much." Or in another instant: "He [Newell] is a true friend of the Union and in every way a reliable gentleman."20

In 1862 , he was among the nominees for the governorship although Marcus $\mathrm{L}$. Ward finally received the nomination only to go on to defeat in the election. A year later Newell stood for

${ }^{23}$ Knapp, pp. I6-1 7. Herman K. Platt, Charles Perrin Smith: New Jersey Political Reminiscences $1828-18.82$ (New Brunswick: Rutgers University Press, 1965), pp. 104-105.

${ }^{24}$ Knapp, p. 27. Platt, pp. 22 x-225.

${ }^{25}$ The Collected Works of Abraham Lincoln, Roy P. Basler, ed. (New Brunswick: Rutgers University Press, 1953), I, 497; IV, 405, 502; V, I36, 179; VI, 191, 460; VII, $263-264,353,543$.

${ }^{26}$ Ibid., IV, 405; VII, 543. Newell secured commissions for his brother John W. Newell and Moses F. Webb as paymasters and Nehemiah Merritt as aide-de-camp to General Fremont. 
election to the United States Senate although the legislature was firmly in the hands of the Democrats and election next to impossible. Democratic supremacy endured through $\mathrm{r} 864$ as McClellan carried the state in the presidential election, and the state government remained under Democratic control. But Newell regained his congressional seat that year despite the Democratic triumphs. ${ }^{27}$

Newell's third term in the Congress was occupied primarily with the problems associated with the controversy over reconstruction policies and procedures. He took the floor on February i 5, i 866, demonstrating his natural propensities for a moderate position on complex issues. Newell asserted his confidence in President Johnson, holding that "there is no material difference on vital points between him [Johnson] and ourselves; none that may not be speedily adjusted by conference and conciliation." ${ }^{28}$ He feared, however, that a new southern "oligarchy," utilizing extreme and discredited states rights doctrines, would reverse the recent military victory that had vindicated perpetuity of the Union. Although he conceded that full and immediate citizenship for the Negro "may be unwise," he equated freedom and suffrage with citizenship. Newell rejected the "state suicide" theory of Stevens and Sumner and urged the Committee on Reconstruction to proceed with caution. Newell was not a radical on the reconstruction issue, at least not as yet.

By 1866 , the Republican Party enjoyed respectability in New Jersey. Republicans gained control of the legislature, elected a United States Senator and picked up an additional congressional seat. Newell, however, was defeated in his bid for re-election.

The Democrats had circulated a pamphlet, Newell's Record, which sharply attacked Newell as a "do nothing" congressman, a foe of immigrants, and a supporter of Negro suffrage. ${ }^{29}$ It would appear that such tactics would not have been adequate to defeat Newell at a time when Republicans were making substantial strides in New Jersey. Rather, it was charged that Newell was the victim of an intra-party struggle between old Whigs and younger men led by Alexander G. Catell and George M. Robeson, who sought

${ }^{27}$ Knapp, pp. 72, I $15,125,140$.

28 Speech of Honorable William A. Newell of New Jersey in the House of Representatives, February 15, 1866 . Pamphlet in Rutgers University Library.

${ }^{29}$ Nequell's Record! Democratic Party of New Jersey, Second Congressional District, 1 866. Pamphlet in Rutgers University Library. 
control of the Republican Party at the expense of the old leadership if necessary..$^{30}$

In any event Newell removed any doubt about his being "soft" on the reconstruction issues, a charge levelled at him in the campaign. As a "lame duck" congressman he took the floor on January 4, I 867. In tone and substance this speech could serve as a model of radical Republicanism. Newell believed that the reconstruction issues were as momentous as the military struggle to preserve the Union. He demanded immediate and complete civil rights for the Negro, security for the future loyalty of southerners, and the barring of former Confederate leaders from political office. Newell charged President Johnson with "a catalogue of high crimes and misdemeanors," claiming that the President had allied himself with the party of secession and rebellion and consorted with "rebels, traitors and bitter partisan Democrats." Newell joined in the movement to impeach the President. ${ }^{31}$ After leaving Congress Newell continued in the radical reconstruction cause as a member and officer of the Union League's National Executive Committee. ${ }^{32}$

$\mathrm{He}$ accepted the party's nomination in I 870 for Congress and in $187 \mathrm{I}$ for the United States Senate, suffering defeat on each occasion. The last and probably most bitter political experience for Newell was in New Jersey's gubernatorial campaign of I 877 .

The Catell-Robeson faction backed by growing support from the Pennsylvania Railroad Company desired the nomination for one of its own men until the Democrats nominated the popular General George B. McClellan. Many Republicans believed that the campaign was "utterly hopeless." At that point the Catell-Robeson forces threw their full support behind Newell, who won a first ballot nomination. ${ }^{34}$

Perhaps Newell was fully aware of the political realities which had brought him to this unenviable end. His campaign was singularly lacking in balance and moderation. In Camden he attacked the enormous expense of maintaining the National Guard; General

${ }^{30}$ Knapp, p. 157. Platt, pp. I60-163.

${ }^{31}$ Speech of Honorable William A. Newell of New Jersey in the House of Representatives, January 4, 1867 . Pamphlet in Rutgers University Library.

${ }^{32}$ See Union League handbill dated September 20,1870 , in the Rutgers University Alumni Files, William A. Newell, 1836 .

${ }^{33}$ Platt, p. I 90.

${ }^{34}$ Knapp, p. 177 . 
Sewell, a Republican who commanded a National Guard brigade, was offended. At Woodbury, Newell declared that the salaries paid to members of the Fish Commission were a waste; a Republican member of the commission pledged to work for Newell's defeat. In Newark, Newell criticized the Morris Plains Asylum Commission; George A. Halsey, a Republican member of the commission, announced that he would vote an open ticket against Newell. ${ }^{35} \mathrm{Mc}-$ Clellan's majority exceeded I 2,000 votes. ${ }^{\mathbf{3 6}}$

Newell had fought his last political campaign in New Jersey. In I 880 , at the age of 63 , he accepted President Hayes appointment as Governor of the Washington Territory. In the next four years he adapted his traditional conservative principles to the vast and richly endowed frontier environment. He worked for prohibition laws and the exemption of church property from taxation. Two lifesaving stations were established on the Pacific Coast during his administration. Newell advocated abolition of the reservation system as a first step "to place Indians upon the same footing with other people." Near the end of his four-year term the Northern Pacific Railroad was completed, and Newell reported that the territory had drafted a constitution and was ready for admission to the Union. ${ }^{37}$

Newell's last public office in the Washington Territory was that of Indian Commissioner, I 884-1886. He resided in Olympia where he established his medical practice and worked as a resident surgeon at the Soldiers and Sailors Home. After the death of his wife and two sons who had joined him in the Washington Territory, Newell returned to Allentown in $1899 .^{38}$

Honors had come to Newell over the years. Rutgers College conferred a Doctor of Laws degree in $187 \mathrm{I}$, and two years later elected him a trustee. Princeton University also elected him a trustee. In

${ }^{35}$ William E. Sackett, Modern Battles of Trenton (Trenton: John L. Murphy, 1895), pp. I $54^{-1} 55$.

${ }^{36}$ Knapp, p. 177.

${ }^{37}$ Messages of the Governors of the Territory of Washington to the Legislative Assembly, 1854-1889, Charles M. Gates, ed. (Seattle: University of Washington Press, I940), pp. 2 I 7-246.

${ }_{38}$ Cyclopedia of New Jersey, I, 231 . One son, William A. Newell, Jr., was born in Allentown in 1855 . He attended Rutgers Preparatory School, graduated from Rutgers College in 1875 , and took his medical degree at the University of Pennsylvania in I 877. After being injured in a streetcar accident, he joined his father in the Washington Territory where he died in 1886 . Rutgers University Alumni Files, William A. Newell, 1875 . 
I 896, the New Jersey legislature passed resolutions recognizing Newell as the founder and originator of the life-saving service.

Governor Foster M. Voorhees declared a thirty-day mourning period when Newell died in I9OI. Among the many prominent people who attended the funeral services was Dr. Austin Scott, President of Rutgers College. ${ }^{39}$ That institution, now in its twohundredth year, produced alumni who became greater physicians than Newell and politicians whose careers eclipsed Newell's; but few alumni enjoyed, as did William A. Newell, the rich experience to be had by a lifetime of active involvement in both pursuits.

${ }^{39}$ William Nelson, The New Jersey Coast in Three Centuries (New York: The Lewis Publishing Company, 1902), II, 249-254. 